\title{
A GOOD-FAITH CHALLENGE TO THE TAXONOMY OF TORT LAW DEFENCES
}

\author{
IAIN FIELD*
}

\section{INTRODUCTION AND OUTLINE}

Perhaps unsurprisingly, there is no universally accepted taxonomy of tort law defences. ${ }^{1}$ Indeed, at least one influential scholar in the field actively discouraged any attempt to compile a "systematic index of "exceptions" or "defences". 2 Nevertheless, in his ambitious and pioneering book, Tort Law Defences, James Goudkamp endeavours to do precisely this. ${ }^{3}$ Goudkamp's work will be lauded by some ${ }^{4}$ as an important progression in the great 'taxonomical project' - that is to say, the movement given impetus 'by the late Professor Peter Birks and (the mainly academic) supporters and advocates of his and similar views to impose a coherent and logical taxonomy upon private (common) law'. ${ }^{5}$ Whether this is actually Goudkamp's purpose is unclear; it may be that he intends merely to provide an account of tort law defences that is descriptively true. ${ }^{6}$ But whatever the case - and whether his taxonomy is accepted or rejected - Goudkamp is owed a considerable debt for illuminating the need to develop our understanding of this important area of the law, and for laying the foundations upon which we might do so.

Much might be written about whether Goudkamp's book advances or exposes the taxonomical project (if it says anything about it at all), but whichever

* Assistant Professor, Faculty of Law, Bond University. The author is grateful to Joachim Dietrich and Rick Bigwood for their comments on earlier drafts of this article, and to the anonymous reviewers, whose thoughtful and insightful comments led to a number of substantive changes.

1 Various possible taxonomies are nevertheless offered in, or may be gleaned from, the literature. For further discussion, see Part V of this article.

2 John G Fleming, The Law of Torts (Law Book, $9^{\text {th }}$ ed, 1998) 8. The current editors have retained Fleming's remarks: Carolyn Sappideen and Prue Vines (eds), Fleming's The Law of Torts, (Law Book, $10^{\text {th }}$ ed, 2011) 8 .

3 James Goudkamp, Tort Law Defences (Hart Publishing, 2013) 1.

4 See, eg, Eric Descheemaeker, 'Tort Law Defences: A Defence of Conventionalism' (2014) 77 Modern Law Review 493, 506. Paul Mitchell explicitly notes the influence of Birks in Goudkamp's work in his review of Goudkamp's book: Paul Mitchell, 'Book Review: Tort Law Defences' (2014) 36 Sydney Law Review 185, 186.

5 Joachim Dietrich, 'What is "Lawyering”? The Challenge of Taxonomy' (2006) 65 Cambridge Law Journal 549, 549 (citations omitted).

6 A possibility considered in Roderick Bagshaw, 'Balancing Defences' in Andrew Dyson, James Goudkamp and Frederick Wilmot-Smith (eds), Defences in Tort (Hart Publishing, 2015) 87, 89. 
side is taken in such matters, few scholars would seriously deny that some ordering of legal categories is essential to the development and exposition of the law. All tort lawyers must either accept or assume some classification of 'torts' else there would be no 'tort law' to speak of, and it would be impossible to divide textbooks on the subject into meaningful compartments. It is true that the labels attached to these compartments seldom bear any specific legal significance. ${ }^{7}$ However, labels might nevertheless influence the substantive treatment afforded to the underlying legal concepts that they seek to identify, and poorly defined labels might diminish the quality of legal reasoning. As Dagan observes, the 'taxonomic scheme we use in law does not merely organise our legal knowledge; rather, our legal taxonomy necessarily participates in our construction of that knowledge and thus in the ongoing evolution of law' ${ }^{8}$ In truth, then, what scholars are likely to disagree upon is not whether the classification of legal categories is itself important or necessary, but rather the assumptions that guide the classificatory process and the ends to which that process ought to be employed. ${ }^{9}$ For this reason, Dagan speaks not of taxonomists and their 'opponents', but of 'doctrinalist' taxonomists (such as Birks and his supporters) and 'realist' taxonomists (such as himself). ${ }^{10}$

Provided that a robust conceptual distinction can be maintained between 'torts' and tort law 'defences', it may also be possible to classify the latter within certain organising categories. Again, the issue is not whether this process of classification is desirable or necessary, but rather how and to what extent this process might be achieved and the proper object of doing so. What might prove controversial to these ends are matters such as:

1. the definition of the term 'defences' and the precise nature of the distinction (if any) between defences and the torts to which they provide an answer;

2. the level of generality at which categories of defences can or ought to be expressed; ${ }^{11}$

3. whether categories of defences must be discrete and immovable in nature; ${ }^{12}$

4. whether categories of defences merely 'describe, rather than affect, the legal landscape'; ${ }^{13}$

Goudkamp, above n 3, 14-17.

Hanoch Dagan, 'Legal Realism and the Taxonomy of Private Law' in Charles Rickett and Ross

Grantham (eds), Structure and Justification in Private Law: Essays for Peter Birks (Hart Publishing,

2008) $147,156$.

9 See generally Dietrich, above n 5, 550; ibid 160-1.

10 Dagan, above n 8, 151-61.

11 Dagan, above n 8, 162; Andrew Dyson, James Goudkamp and Frederick Wilmot-Smith, 'Central Themes in the Law of Tort Defences' in Andrew Dyson, James Goudkamp and Frederick Wilmot-Smith (eds), Defences in Tort (Hart Publishing, 2015) 3, 12-13. See also the classificatory 'musings' offered by Descheemaeker, above $\mathrm{n} 4,509-11$.

12 For differing views on this issue in the context of private law taxonomy generally, compare Dietrich, above n 5; Dagan, above n 8, 155, 163-4; Peter Birks, 'Introduction' in Peter Birks (ed), English Private Law (Oxford University Press, 2000) vol 1, li; Stephen A Smith, 'Taking Law Seriously' (2000) 50 University of Toronto Law Journal 241, 246-7. 
5. whether a valid taxonomy of defences may exclude definitional outliers; and

6. whether a valid taxonomy of defences may ignore statutory defences. ${ }^{14}$

This article contributes to the growing literature on tort law defences by revealing the taxonomical difficulties posed by 'good faith defences' - that is, defences that exempt certain classes of defendant from civil liability provided that he or she acted in good faith (or bona fide, honestly, without malice, and so forth). ${ }^{15}$ Good faith defences present a unique challenge to the taxonomy of tort law defences because, unlike most other defences to tortious liability, they are ordinarily concerned with a defendant's reasons for engaging in impugned conduct, despite the fact that those reasons - though formed by or influencing a rational mind - may be insufficient to render that defendant's conduct objectively reasonable. ${ }^{16}$ As such, and depending on how one defines and distinguishes between specific categories of defence, good faith defences might also impugn the conventional view that tort law does not recognise 'excuses' ${ }^{17}$ Certain good faith (and other similar) protections also defeat liability in damages but do not preclude a discretionary remedy, and might for this reason frustrate attempts to articulate a universal definition of the term 'defences'.

The argument develops incrementally in five substantive parts. Part II outlines the range of circumstances in which good faith 'protections' (to use a neutral term that encompasses, but is not limited to, the possible definitions of 'defences' examined later in this article) operate in tort law, and demonstrates why - subject to the qualifications subsequently outlined - good faith protections should be included in a comprehensive taxonomy of tort law defences. Part III critiques possible definitions of the term 'defences' and demonstrates why good faith (and other similar defences) fit uneasily with these definitions. Part IV explores in greater depth the meaning of good faith and shows that, in tort law, this concept ordinarily denotes a defendant's reasons for acting, despite the fact that those reasons may be insufficient to render his or her conduct reasonable. Part V explores three competing taxonomies of tort law defences and demonstrates why, in the light of the critical features of good faith defences

13 Dagan, above n 8, 160.

14 James Goudkamp and John Murphy conclude that they cannot: James Goudkamp and John Murphy, 'Tort Statutes and Tort Theories' (2015) 131 Law Quarterly Review 133, 136-7. See also T T Arvind and Jenny Steele, 'Introduction: Legislation and the Shape of Tort Law' in T T Arvind and Jenny Steele, Tort Law and the Legislature: Common Law, Statute and the Dynamics of Legal Change (Hart Publishing, 2013) 1, 1-2.

15 Good faith might also operate as a precondition to a defence of statutory authority: see, eg, $C P C F v$ Minister for Immigration and Border Protection (2015) 255 CLR 514, 581 [200] (Crennan J), 620 [360] (Gageler J).

16 Certain common law defences in tort law are, of course, sensitive to reasons that are insufficient to render conduct reasonable. One example is the defence of fair comment, which might defeat liability in defamation. However, this article is primarily concerned with statutory defences.

17 See, eg, Dyson, Goudkamp and Wilmot-Smith, above n 11, 22, citing John C P Goldberg, 'Tort Law's Missing Excuses' in Andrew Dyson, James Goudkamp and Frederick Wilmot-Smith, Defences in Tort Law (Hart Publishing, 2015) 53. See also John C P Goldberg, 'Inexcusable Wrongs' (2015) 103 California Law Review 467. 
revealed in Parts II-IV, these (and other similar) defences pose a specific challenge to certain of those taxonomies. Finally, Part VI offers some preliminary conclusions as to how good faith defences might be accommodated within a comprehensive taxonomy of tort law defences.

\section{SHOULD GOOD FAITH PROTECTIONS BE INCLUDED IN A TAXONOMICAL ACCOUNT OF TORT LAW DEFENCES?}

Good faith protections have been available in one form or another for centuries, ${ }^{18}$ and a casual search of legislative databases in most common law jurisdictions will reveal multitudinous contemporary examples of such protections that defeat, limit, shift or indemnify the liability of governmental bodies and employees, ${ }^{19}$ police officers and administrators, ${ }^{20}$ emergency services personnel $^{21}$ and health care practitioners and authorities. ${ }^{22}$ An example of such a protection can be seen in s 78 of the Fire Brigades Act 1989 (NSW):

18 See, eg, Secretary, Department of Education, Employment, Training \& Youth Affairs (Cth) v Prince (1997) 152 ALR 127, 130 (Finn J).

19 In Australia, see, eg, Fisheries Management Act 1991 (Cth) s 90; Local Government Act 1993 (NSW) s 731; Local Government Act 1995 (WA) s 9.56; Criminal Injuries Compensation Act 2003 (WA) s 66. In Canada, see, eg, Royal Canadian Mounted Police Act, RSC 1985, c R-10, s 45.5(1); Tax Appeals Commission Act, CCSM 1993, c T3, s 11(1); City of Winnipeg Charter Act, SM 2002, c 39, s 472; Protection for Persons in Care Act, CCSM 2013, c P144, s 15; Fire Prevention Act, RSNB 1973, c F-13, s 6.1; An Act Respecting the Health and Social Services Ombudsman, CQLR 2006, c P-31.1, ss 30-1. In New Zealand, see, eg, Biosecurity Act 1993 (NZ) s 164; Maritime Transport Act 1994 (NZ) s 327; Customs and Excise Act 1996 (NZ) ss 38P, 175, 280E(2); Trademarks Act 2002 (NZ) ss 134ZF, 155K, 175D. In the United Kingdom, see, eg, Public Health Act 1875 (UK) c 55, s 265; Sea Fisheries (Shellfish) Act 1967 (UK) c 83, s 4D(1), as inserted by Police, Public Order and Criminal Justice (Scotland) Act 2006 (Scot) asp 10, s 98; Proceeds of Crime Act 2002 (UK) c 9, s 338(4A) as inserted by Serious Crime Act 2015 (UK) c 9, s 37; Environment Act 1995 (UK) c 25, sch 18 para 6(4); Noise and Statutory Nuisance Act 1993 (UK) c 40, sch 3 para 12; Clean Neighbourhoods and Environment Act (Northern Ireland) 2011 (NI) c 23, s 58(9); Inquiry into Historical Institutional Abuse Act (Northern Ireland) 2013 (NI) c 2, s 18; Local Audit and Accountability Act 2014 (UK) c 2, sch 8 para 4(3). In Ireland, see, eg, Freedom of Information Act 2014 (Ireland) s 49(4).

20 In Australia, see, eg, Police Act 1990 (NSW) s 213; Police Administration Act 1978 (NT) ss 116G, 148B; Police Powers and Responsibilities Act 2000 (Qld) ss 38, 122, 787; Police Act 1998 (SA) s 65; Police Service Act 2003 (Tas) s 84; Police Act 1892 (WA) s 137. In New Zealand, see, eg, International Terrorism (Emergency Powers) Act 1987 (NZ) s 16; Search and Surveillance Act 2012 (NZ) ss 165-6. In the United Kingdom, see, eg, Police Reform and Social Responsibility Act 2011 (UK) c 13, sch 1 para 15; Serious Organised Crime and Police Act 2005 (UK) c 15, s 90.

21 In Australia, see, eg, Fire Brigades Act 1989 (NSW) s 78; Fire and Emergency Act 1996 (NT) s 47; Fire and Emergency Services Act 1990 (Qld) ss 153B-C; Fire Service Act 1979 (Tas) s 121; Country Fire Authority Act 1958 (Vic) s 18A; Fire and Emergency Services Act 1998 (WA) s 37. In Canada, see, eg, Transportation of Dangerous Goods Act, SC 1992, c 34, s 20; Emergency 911 Act, RSNB 2011, c 146, s 8; Firefighters' Protection Act, SNL 1996, c F-11.1, s 3; Fire Protection and Prevention Act, SO 1997, c 4, s 74. In New Zealand, see, eg, Fire Services Act 1975 (NZ) s 43; Forest and Rural Fires Act 1977 (NZ) s 56. In the United Kingdom, see, eg, Combined Fire Authorities (Protection from Personal Liability) (Wales) Order 1997 (UK) SI 1997/2818, O 3.

22 In Australia, see, eg, Mental Health Act 2015 (ACT) s 265; Mental Health Act 2007 (NSW) s 191; Mental Health and Related Services Act 1998 (NT) s 164; Mental Health Act 2000 (Qld) s 536; Mental Health Act 2013 (Tas) s 218; Mental Health Act 2014 (Vic) s 77(2); Mental Health Act 2014 (WA) ss 583-4. In Canada, see, eg, Human Tissue Gift Act, RSBC 1996, c 211, s 9; Human Tissue Gift Act, RSS 1978, c H- 
A matter or thing done, or omitted to be done, by the Minister, the Commissioner, any member of staff of Fire and Rescue NSW, any member of a fire brigade, any member of a community fire unit or any person acting under the authority of the Commissioner does not, if the matter or thing was done, or omitted to be done, in good faith for the purposes of executing this or any other Act, subject such a person personally, or the Crown, to any action, liability, claim or demand.

Good faith protections are not the exclusive preserve of public sector defendants, however; various private persons - such as volunteers, ${ }^{23}$ rescuers, ${ }^{24}$ trademark infringers, ${ }^{25}$ postal workers ${ }^{26}$ and others ${ }^{27}$ - might also invoke a good faith protection in certain instances. Thus, even if one were to take the view that there is a substantive difference between a law of torts concerned with governmental conduct and one concerned with the conduct of private persons, good faith protections cannot be excluded on this basis from a taxonomical account of the defences available in either. In any event, each of the taxonomies considered later in this article accept that statutory authority is a defence in tort law, despite the fact that it is available mainly, if not exclusively, to public servants.

The position in the United States ('US') is slightly different, in that various US states afford public officials a qualified good faith immunity at common law. ${ }^{28}$ Some such 'immunities' have been replaced or repealed by statute, ${ }^{29}$ and in other US states the subjective good faith element of the immunity has fallen out

15, s 10. In New Zealand, see, eg, Land Transport Act 1998 (NZ) s 18(3). In the United Kingdom, see, eg, Public Health (Control of Disease Act) 1984 (UK) c 22, s 69.

23 In Australia, see, eg, Commonwealth Volunteers Protection Act 2003 (Cth) ss 6-7; Civil Law (Wrongs) Act 2002 (ACT) ss 8-9; Civil Liability Act 2002 (NSW) s 61; Personal Injuries (Liability and Damages) Act 2003 (NT) s 7; Civil Liability Act 2003 (Qld) s 39; Volunteers Protection Act 2001 (SA) s 4; Civil Liability Act 2002 (Tas) s 47; Wrongs Act 1958 (Vic) s 37; Volunteers and Food and Other Donors (Protection from Liability) Act 2002 (WA) ss 6-7.

24 In Australia, see, eg, Civil Law (Wrongs) Act 2002 (ACT) s 5; Civil Liability Act 2002 (NSW) s 57; Personal Injuries (Liabilities and Damages) Act 2003 (NT) s 8; Civil Liability Act 2003 (Qld) s 26; Civil Liability Act 1936 (SA) s 74; Civil Liability Act 2002 (Tas) s 35B; Wrongs Act 1958 (Vic) s 31B; Civil Liability Act 2002 (WA) s 5AD. In Canada, see, eg, Chase McEachern Act (Heart Defibrillator Civil Liability), SO 2007, c 10, s 2; Defibrillator Public Access Act, SM 2011, c 10, s 15; Automated Defibrillator Act, SNB 2009, c A-17.5, s 2.

25 See, eg, Trade Marks Act 1995 (Cth) ss 122(1)(a)-(c).

26 See, eg, Australian Postal Corporation Act 1989 (Cth) s 90ZC.

27 See, eg, Corporations Act 2001 (Cth) s 184. In Canada, see, eg, Tobacco and Vapour Products Control Act, SNL 1993, c T-4.1, s 6; Tobacco and Electronic Smoking Device Sales and Access Act, RSPEI 1988, c T-3.1, s 7. In Ireland, see, eg, Consumer Protection Act 2007 (Ireland) s 87.

28 See, eg, Smith v Stafford, 189 P 3d 1065, 1074 (Carpeneti J) (Alaska, 2008); Stiebitz v Mahoney, 134 A 2d 71, 74 (O’Sullivan CJ) (Conn, 1957); Rowan Country v Sloas, 201 SW 3d 469, 474 (Scott J) (Ky, 2006); Eliason v Funk, 196 A 2d 887, 888 (Henderson J) (Md, 1964); Mandel v O'Hara, 576 A 2d 766, 769 (Rodowsky J) (Md, 1990); Peterson v George, 96 NW 2d 627, 632 (Wenke J) (Neb, 1959); Bedrock Foundations Inc v Geo H Brewster \& Son Inc, 155 A 2d 536, 544-6 (Jacobs J) (NJ, 1959). However, in other US jurisdictions - including federal jurisdiction - the immunity of public officials is qualified by 'objective reasonableness': Harlow v Fitzgerald, 457 US 800, 818 (Powell J) (1982); Anderson v Creighton, 483 US 635 (1987). The position in the US is considered further in Part V(B) below. See also Seth P Waxman and Trevor W Morrison, 'What Kind of Immunity? Federal Officers, State Criminal Law, and the Supremacy Clause' 112 Yale Law Journal 2195, 2209-11.

29 In Wyoming, for example, the qualified good faith immunity recognised in Oyler $v$ Wyoming, $618 \mathrm{P} 2 \mathrm{~d}$ 1042 (Wyo, 1980) appears to have been replaced by a general statutory immunity created by Wyo Stat Ann § 1-39-104 (LexisNexis 2016). 
of favour. ${ }^{30}$ Nevertheless, all 50 US states afford statutory good faith protections to certain classes of defendant, both private and public. ${ }^{31}$

Although good faith protections are largely ignored in the tort law literature, ${ }^{32}$ they have generated a considerable body of case law, ${ }^{33}$ and the courts have gone to considerable lengths to construe 'such provisions by reference to general principles rather than by a textual analysis of individual enactments' ${ }^{34}$ In the result, good faith protections adopt remarkably similar, if not identical, language to achieve their ends, and it seems self-evident that they form a coherent and distinct legal category. ${ }^{35}$ The very existence of good faith protections is also likely to have had some effect upon the development of substantive tort law principles. This is because, given the choice, plaintiffs are less likely to pursue defendants who belong to a protected class than they are to pursue defendants who belong to an unprotected class. ${ }^{36}$

For the preceding reasons, and to the extent that they may be defined as 'defences' - on which more below - it is clear that good faith protections should be included within any comprehensive taxonomy of tort law defences. As Goudkamp and Murphy observe, 'a theory of the law that purports to explain the law but which is unable account for significant parts of it is unsatisfactory'. ${ }^{37}$ To exclude good faith protections that constitute defences from an account of tort law defences would be to ignore the important normative role that these defences play, and have played, in shaping the boundaries of tortious liability. Since legal taxonomies also influence the ongoing development of the law, omitting good faith defences from taxonomies of tort law defences might also affect, rather than merely describe, the legal landscape in this area.

30 See, in particular, the reasons given by the Supreme Court of the United States to abandon the previously recognised subjective good faith aspect of qualified immunity in Harlow v Fitzgerald, 457 US 800, 81319 (Powell J) (1982).

31 In May v Southeast Wyoming Mental Health Center, 866 P 2d 732 (Wyo, 1993) the Supreme Court of Wyoming observed that all 'fifty states have a statute similar to Wyo.Stat. § 14-3-209 which provides immunity for persons who report suspected abuse provided the reporting was done in good faith': at 738 (Brown J).

32 In contrast, good faith defences have received some attention in the American criminal law literature: see, eg, Laurie L Levenson, 'Good Faith Defenses: Reshaping Strict Liability Crimes' (1993) 78 Cornell Law Review 401.

33 In Spooner v Juddow (1850) 6 Moo PC 257, 283; 13 ER 682, 692, Lord Campbell declared that the English reports 'actually swarm with decisions' to the effect that there is 'no rule more firmly established, than that if parties bona fide and not absurdly believe that they are acting in pursuance of Statutes, and according to law, they are entitled to the special protection which the Legislature intended for them'.

34 Webster v Lampard (1993) 177 CLR 598, 619 (McHugh J).

35 See, eg, Iain Field, 'Good Faith Defences in Tort Law' (2016) 38 Sydney Law Review 147, 155-8.

36 See Iain Field, 'Good Faith Protections and Public Sector Liability' (2016) 23 Torts Law Journal 210, 215-16.

37 Goudkamp and Murphy, above n 14, 136. 


\section{GOOD FAITH 'DEFENCES'?}

\section{A Denials}

What, then, is a 'defence', and can all good faith protections be classified as such? A significant challenge in answering the first part of this question is that it is difficult to articulate a logical distinction between 'defences' on the one hand, and 'denials' of liability - that is to say, 'pleas by the defendant that one of the elements of the tort in which the claimant sues is missing' 38 - on the other. Indeed, on one view, denials and defences are really 'just different names for two subsets of circumstances whose function is precisely the same'. ${ }^{39}$ As Stone famously remarked:

What is the difference in logic between a quality of a class as contained in the definition of the class, and a quality of a class as contained in an exception to the class? The answer appears to be - none at all. Every qualification of a class can equally be stated without any change of meaning as an exception to a class not so qualified. Thus the proposition 'All animals have four legs except gorillas', and the proposition 'All animals which are not gorillas have four legs', are, so far as their meanings are concerned, identical. ${ }^{40}$

In terms, Stone's reasoning is unassailable. It might also prove fatal to the ambitions of doctrinalist taxonomists in this area, for whom overlapping categories are anathema. To others, though, the classification of legal categories is important only insofar as this might facilitate the analysis of like with like, as opposed to the separation of like from unlike. Why, such a person might ask, should the classification of an exception be rejected simply because the outcome of applying that exception as a qualification to a specific class (or tort) is logically the same as if the meaning of that class were itself modified? Unless taxonomy is merely an end in itself there can be no satisfactory answer to this question; a gorilla is still a 'gorilla' even if the fact that it has two legs might be said to qualify the definition of 'animals'. It might be for this reason that Cane avoids the term 'defence' and employs the broader term 'answer', which does not distinguish between defences and denials. ${ }^{41}$

There are, in any event, important interpretive and practical reasons for rejecting the conclusion that certain protections should be classified as denials, especially when those protections might be applied to numerous torts. Most good faith protections could in theory provide an answer to any number of torts (and other civil actions), and it seems highly unlikely that legislatures - or, in certain US states, the judiciary - would seek to modify multiple possible causes of action

38 Goudkamp, above n 3, 1-5, 46. See also John Gardner, Offences and Defences: Selected Essays in the Philosophy of Criminal Law (Oxford University Press, 2007) 79; Goldberg, 'Inexcusable Wrongs', above n $17,470-1$.

39 Luís Duarte d'Almeida, 'Defining Defences' in Andrew Dyson, James Goudkamp and Frederick WilmotSmith (eds), Defences in Tort (Hart Publishing, 2015) 35, 52 (emphasis in original). See also Glanville Williams, 'The Logic of Exceptions' (1988) 47 Cambridge Law Journal 261, 277.

40 Julius Stone, 'Burden of Proof and the Judicial Process: A Commentary on Joseph Constantine Steamship Ltd v Imperial Smelting Corporation Ltd' (1944) 60 Law Quarterly Review 262, 280 (citations omitted).

41 Peter Cane, Responsibility in Law and Morality (Hart Publishing, 2002) 89-90, 90 n 83. 
in order to protect a specific and limited class of defendant. ${ }^{42}$ Interpreting good faith protections as denials might also generate unnecessary complexity in the law, especially in the context of torts, such as negligence, which already comprise highly nuanced or multifaceted liability-establishing fault criteria. For these reasons, courts are far more likely to interpret good faith protections as exceptions to liability than as denials of liability.

\section{B Defences}

Of course, it does not follow from the conclusion that good faith protections are more likely to be interpreted as exceptions to liability than as denials of liability that they are necessarily defences, and the question remains as to how the term 'defences' ought to be defined. One definition that might vindicate 'our pre-theoretical hypothesis' that denials and defences 'are importantly different' 43 - and which might be implicit in conventional accounts of tort law defences ${ }^{44}$ is that defences are matters that the defendant bears the burden of proving. No reason in law or logic demands that this definition must be adopted, ${ }^{45}$ and it may indeed '[draw] within its net many rules that no one would intentionally count as defences' 46 - on which more below. However, most good faith protections would satisfy this definition. This is because, if a statutory provision 'expresses an exculpation, justification, excuse, ground of defeasance or exclusion which assumes the existence of the general or primary grounds from which the liability or right arises' ${ }^{47}$ courts will ordinarily assume - absent some 'identified contrary legislative indication' 48 - that the onus of proving the terms of that provision rests on the defendant. A similar presumption applies if the provision in question purports to defeat liability in respect of conduct connected to the exercise of statutory powers. ${ }^{49}$

42 See also Goudkamp, above n 3, 193-6.

43 Duarte d'Almeida, above n 39, 45.

44 Descheemaeker, above n 4, 499.

45 See, eg, Robert Stevens' observation that the 'onus of proof' rule is 'not logically necessary however, and should not be thought of as a defining feature of what a defence is. The law could be that the onus of proof in all matters fell upon the defendant. This would not turn the entire law into a law of defences': Robert Stevens, 'Should Contributory Fault be Analogue or Digital?' in Andrew Dyson, James Goudkamp and Frederick Wilmot-Smith (eds), Defences in Tort (Hart Publishing, 2015) 247, 250. This definition might also exclude various rules conventionally described as defences. For example, to overcome a defence of qualified privilege in an action for defamation, the plaintiff must prove malice: Clark v Molyneux (1877) 3 QBD 237, 246-7 (Brett LJ); Bashford v Information Australia (Newsletters) Pty Ltd (2004) 218 CLR 366, 377 [22] (Gleeson CJ, Hayne and Heydon JJ). Goudkamp studiously avoids narrowing his definition of defences in this way: Goudkamp, above n 3, 3-5.

46 Goudkamp, above n 3, 6.

47 Vines v Djordjevitch (1955) 91 CLR 512, 519-20 (Dixon CJ, McTiernan, Webb, Fullagar and Kitto JJ), citing numerous authorities including Darling Island Stevedoring \& Lighterage Co Ltd v Jacobsen (1945) 70 CLR 635; Dowling v Bowie (1952) 86 CLR 136.

48 Webster v Lampard (1993) 177 CLR 598, 606 (Mason CJ, Deane and Dawson JJ).

49 Rochfort v Rynd (1881) 8 LR Ir 204, 209-10 (Palles CB); Sayer v Lichfold (1854) 23 LT 324, 325 (Parke B); Newell v Starkie (1919) 83 JP 113, 117 (Lord Finlay); Bankstown City Council v Alamdo Holdings Pty Ltd 223 CLR 660, 675-6 [54]-[55] (Gleeson CJ, Gummow, Hayne and Callinan JJ). Cf Hamilton v Halesworth (1937) 58 CLR 369, 380 (Dixon and McTiernan JJ). 
An alternative definition, proposed by Goudkamp, is that defences are 'liability-defeating rules that are external to the elements of the claimant's action'. ${ }^{50}$ This definition, Goudkamp tells us, 'brings into focus the fundamental difference between rules that define torts and rules that release from liability a defendant whose conduct constitutes a tort'. ${ }^{51}$ It is debatable whether this definition does identify a fundamental difference between defences and denials, since it might be argued that the effect of a denial is also to defeat a defendant's liability, and in order to conclude that a rule is external to a claimant's action one must concede that defences and denials can be distinguished in the first place. If it is accepted that good faith protections are unlikely to be interpreted as denials, for the reasons outlined above, then the second of these observations is of little consequence for present purposes.

However, if the view is taken that a rule must defeat liability to qualify as a defence then a number of interesting questions arise as to whether all good faith protections and other similar protections - assuming they are not denials of liability - are, in all instances, defences. These questions are raised by three, sometimes overlapping species of good faith protection, which are described here as: indemnities; liability-shifting protections; and remedy-limiting protections.

\section{Good Faith Indemnities}

In certain instances, good faith protections operate by shifting a defendant's ('D1') legal obligation to pay costs, damages, or both to his or her employer ('D2'), without preventing D1 from being named in proceedings (a 'good faith indemnity'). For example, section 43 of the Local Government Act 2002 (NZ) states that:

(1) A member of a local authority ... is indemnified by that local authority ... for-

(a) costs and damages for any civil liability arising from any action brought by a third party if the member was acting in good faith and in pursuance (or intended pursuance) of the responsibilities or powers of the local authority ...

Good faith indemnities transfer D1's obligation to pay damages to D2; however, they do not prevent the plaintiff ('P') from obtaining damages in respect of D1's wrong. Rather, good faith indemnities seek to shield D1 from certain risks - and to transfer the obligation to pay damages for the materialisation of those risks to D2 - without defeating the capacity of $\mathrm{P}$ to obtain an award in damages for D1's wrong, and without preventing D1 from being named in legal proceedings. ${ }^{52}$ It follows that good faith indemnities are not defences according to Goudkamp's definition because they do not defeat liability on any sensible definition of this term. In contrast, if an onus of proof account of defences is adopted good faith indemnities are likely to constitute defences in

50 Goudkamp, above n 3, 2.

51 Ibid 6-7.

52 For example, the object of the Public Service Act 2008 (Qld), s 26C of which affords a good protection to Queensland state employees, is 'to innovate and improve service delivery without the concern of being sued and the accompanying financial risk': Explanatory Notes, Public Service and Other Legislation (Civil Liability) Amendment Bill 2013 (Qld) 1. 
most instances. This is clearly inappropriate, and supports Goudkamp's conclusion that this definition of defences draws too wide a net.

\section{Liability-Shifting Protections}

A more complex definitional challenge is presented by a species of good faith protection that defeats the personal liability of the defendant ('D1'), while simultaneously creating a cause of action against that defendant's employer ('D2') ('liability-shifting protections'). An example of a liability-shifting protection can be seen in section 84 of the Police Service Act 2003 (Tas):

(1) A police officer does not incur any personal liability for any act or omission done or made in good faith in the exercise or performance, or purported exercise or performance, of any powers or duties at common law or under this or any other Act or law.

(2) A liability that, but for subsection (1), would lie against a police officer, lies against the Crown. ${ }^{53}$

Liability-shifting protections are similar in form and function to good faith indemnities, as both species of protection seek to shield D1 from certain risks by transferring liability for those risks to D2, without defeating the capacity of the plaintiff ('P') to obtain damages for D1's wrong. Crucially, however, whereas indemnities accept D1's liability, and ought not to be classified as defences for this reason, liability-shifting protections defeat D1's personal liability entirely. ${ }^{54}$ As such, liability-shifting protections might constitute defences according to Goudkamp's definition, ${ }^{55}$ depending upon what, precisely, is meant by the term 'liability-defeating'.

Although it may be possible to define the term 'liability' in a variety of ways - which definitions might place more or less emphasis on the defendant's obligations vis-à-vis the plaintiff's rights (and vice versa) - the conventional view would appear to be that liability is a relational concept. ${ }^{56}$ So conceived, liability describes a specific defendant's obligation to afford a remedy to a specific plaintiff, and cannot be defined in purely plaintiff- or defendant-relative terms. Although Goudkamp does not say so expressly - presumably because all of the rules that he identifies as defences defeat liability in this sense - it seems likely that this is the meaning of liability that he embraces. If this is correct, then

53 The classification of this and other similar provisions as 'liability-shifting' assumes that its subsections are to be read together as forming part of a single 'protection'. An alternative view is that ss $84(1)$ and $84(2)$ are entirely distinct, such that s $84(1)$ is properly classified as a defence and that s 84(2) imposes a new and discrete liability on the Crown. This alternative interpretative approach is rejected here, however, as it ignores the fact that, as a result of s 84(2), s 84(1) has little, if any, effect on private rights (on which more below).

54 Liability-shifting provisions operate by displacing certain common law presumptions that would otherwise prevent the imposition of vicarious liability on the employer of the protected defendant. These presumptions, and the effect of good faith indemnities upon them, are examined further in Field, 'Good Faith Protections and Public Sector Liability', above n 36.

55 In this respect good faith indemnities may be contrasted with contributory negligence and the doctrine of mitigation, which merely limit the quantum of damages: Goudkamp, above n 3, 3 .

56 This view accords with Hohfeld's conception of 'rights' and 'duties' as correlative concepts, the relationship between which he encapsulates in the word 'claim': Wesley Newcomb Hohfeld, 'Some Fundamental Legal Conceptions as Applied in Judicial Reasoning’ (1913) 23 Yale Law Journal 16, 32. 
liability-shifting protections are defences according to Goudkamp's definition because the effect of such a protection is to defeat liability as between P and D1, albeit not to defeat - and indeed to create - liability as between P and D2. ${ }^{57}$

The classification of liability-shifting protections as defences is problematic for various reasons. Perhaps the most obvious difficulty is that, in function and in practice, liability-shifting protections enhance the capacity of plaintiffs to obtain damages, and thus affirm their rights by creating a cause of action against another party. In contrast, most defences frustrate entirely a plaintiff's rights by removing the defendant's secondary obligation to afford a remedy. While there is no particular reason to insist that a defence cannot at once defeat and create liability, to define a provision that operates in this way as a defence would be counterintuitive to say the least.

The inclusion of liability-shifting protections in an analysis of good faith defences might also lead to substantive error. Since a liability-shifting protection does not defeat a plaintiff's capacity to obtain damages, the disclosed and undisclosed policy considerations that guide the judicial interpretation of that protection might differ from those that influence the interpretation of a good faith defence. This is because protections that purport to limit the capacity of plaintiffs to exercise their rights are construed in a manner protective of those rights (that is, courts are less likely to hold that the protection applies), ${ }^{58}$ whereas protections that facilitate the realisation of private rights by affording access to 'deeper pockets' might be interpreted more liberally to this end (that is, courts are more likely to hold that the protection applies and that liability is transferred). It follows that liability-shifting protections should not be classified as defences, despite the fact that they satisfy Goudkamp's definition of that term.

\section{E Remedy-Limiting Good Faith Protections}

Good faith protections are typically framed so as to defeat civil liability in unabridged terms. Nevertheless, some protections ('remedy-limiting' protections) merely defeat liability in damages - they do not defeat a defendant's secondary obligation to afford injunctive relief, ${ }^{59}$ or, perhaps, some other discretionary remedy. ${ }^{60}$ It may be that most good faith immunities in the US are in fact remedylimiting protections, ${ }^{61}$ and it seems reasonable to suppose that, absent clear language to the contrary, courts in other common law jurisdictions would

57 The same conclusion is reached, of course, if an onus of proof account of defences is adopted.

58 See, eg, Morris v Beardmore [1981] AC 446, 463-4 (Lord Scarman); Wheeler v Leicester City Council [1985] AC 1054, 1065 (Browne-Wilkinson LJ); Bropho v Western Australia (1990) 171 CLR 1, 18 (Mason CJ, Deane, Dawson, Toohey, Gaudron and McHugh JJ); Coco v The Queen (1994) 179 CLR 427, 436-8 (Mason CJ, Brennan, Gaudron and McHugh JJ).

59 For example, Public Service Act 2008 (Qld) s 26C does not 'preclude an employee being named in proceedings or prevent a court or tribunal making orders or issuing injunctions about specific conduct by employees, such as orders to cease contraventions of an Act': Explanatory Notes, Public Service and Other Legislation (Civil Liability) Amendment Bill 2013 (Qld) 5.

60 Other discretionary (coercive) remedies - such as a declaration or an account of profits - might be awarded in respect of tortious conduct, but these possibilities need not be explored here.

61 For example, in Morse v Frederick, 551 US 393 (2007), Breyer J stated that "[a] "qualified immunity" defense applies in respect to damages actions, but not to injunctive relief': at 432. 
ordinarily construct a good faith protection (and other similar statutory protections) so as to preserve their discretion to afford injunctive relief in appropriate cases. This is because the express or implied legislative purpose of most good faith protections is to protect certain groups of defendants from financial risks, ${ }^{62}$ not to allow such defendants to continue tortious interferences with private rights. This raises an important question: must a protection defeat all possible remedies in order to constitute a defence in tort law?

Goudkamp does not attempt to answer this question, or indeed to consider the relationship between tort law defences and discretionary remedies at all. However, a definition of defences that requires all possible remedies to be defeated should be rejected. ${ }^{63}$ If the term 'defences' were reserved for rules that always defeat all possible remedies, then most good faith protections (and many other statutory protections) would fail to qualify as defences merely because, in certain legislatively unspecified and exceptional circumstances, they might not defeat a claim for injunctive relief. On this approach, a statutory protection would only constitute a defence if the possibility of awarding an injunction were specifically excluded by the legislature (which does not occur in practice), or if the protection is limited - in terms or by implication ${ }^{64}$ - to claims in respect of which an injunction is historically unavailable, namely negligence. ${ }^{65}$ This approach might result in the clear demarcation of defences from other protections, but it does not appeal to common sense as it excludes too much.

Another option would be to accept that the proper classification of a protection varies according to whether it defeats all possible remedies in the circumstances. If this view were adopted, then a particular good faith protection, or any number of other statutory protections, may or may not qualify as a defence depending upon the cause of action against which it is deployed. For example, a protection might qualify as a defence when it defeats a claim in negligence, but not, say, when it defeats a claim in trespass to land. This definitional approach would be less indiscriminate than the former approach, but it would still exclude many protections that one might intuitively describe as defences. It is also unlikely to satisfy the doctrinal taxonomist as it precludes the possibility of definitively classifying a particular rule as a defence or as some other form of protection.

For these reasons, the better view may be that a protection must simply defeat liability in damages - the only remedy that arises as of right in respect of all torts

\footnotetext{
62 See above $\mathrm{n} 52$, below $\mathrm{n} 73$.

63 See, similarly, Bagshaw's stated preference for a typology that 'groups together as "defences" those doctrines that allow a defendant to resist in whole, or in part, a tort claim, other than by denying an essential element of it': Bagshaw, above n 6,92.

64 For example, this limitation is ordinarily implied in respect of protections that extend to acts done in good faith 'for the purposes of' a particular statute, as opposed to 'pursuant to' a particular function (or words to that effect): see, eg, Colbran v State of Queensland [2007] 2 Qd R 235, 241 [10] (Williams J).

65 J D Heydon, M J Leeming and P G Turner, Meagher, Gummow and Lehane's Equity: Doctrines and Remedies (LexisNexis Butterworths, $4^{\text {th }}$ ed, 2002) 716 [21-105]; Miller v Jackson [1977] QB 966, 980 (Lord Denning MR); cf SBEG v Commonwealth of Australia (2012) 208 FCR 235, 238-9 [15]-[20] (Keane CJ, Lander and Sipois JJ).
} 
- in order to constitute a defence according to Goudkamp's definition. ${ }^{66}$ If this is correct, then Goudkamp would classify the majority of good faith protections as defences, even if they do not defeat all possible remedies. This definitional approach is also open to challenge, of course, since it accepts that a protection might be classified as a defence despite the fact that it does nothing to prevent an injunction or some other coercive remedy being awarded against the defendant. Given the apparent rarity of such an occurrence, though, this definition seems preferable to one that would exclude a large number of good faith (and other similar) protections. In any event, the remainder of this article proceeds on this basis. Whether it is possible to articulate a definition of defences that traverses the difficulties here outlined is a matter upon which others might wish to ruminate.

\section{THE MEANING OF 'GOOD FAITH' IN TORT LAW}

\section{A Motive and Belief (Subjective Good Faith)}

The precise meaning of good faith varies according to the context in which it operates and the nature of the power, if any, that it constrains. ${ }^{67}$ It is nevertheless central to the arguments advanced in this article that, in its core sense, good faith in tort law describes one or more of a defendant's motives (or reasons) for engaging in impugned conduct, and this assertion must be defended before proceeding further. ${ }^{68}$ It is true that good faith is also routinely interpreted as describing the quality of a defendant's beliefs, whether as to the existence of certain facts (such as an emergency), laws (such as a belief that the impugned conduct is authorised by statute), ${ }^{69}$ or both (such as the guilt of another party). ${ }^{70}$ Employed in this way, however, beliefs would appear to operate as proxies for

66 Thus, a rule that merely removes a court's discretion to award an equitable remedy in certain prescribed circumstances, yet leaves the defendant liable in damages, does not constitute a 'defence' according to Goudkamp because the cause of action is not 'defeated' at common law. Cf Bagshaw, for whom a doctrine that 'prevent[s] a claimant from being awarded an injunction if he or she has waited too long before seeking such a remedy' would qualify as a 'defence': Bagshaw, above n 6, 92.

67 Little v Commonwealth (1947) 75 CLR 94, 112 (Dixon J); Mid Density Developments Pty Ltd v Rockdale Municipal Council (1993) 44 FCR 290, 299-300 (Gummow, Hill and Drummond JJ); Bankstown City Council v Alamdo Holdings Pty Ltd (2005) 223 CLR 660, 674-5 [51] (Gleeson CJ, Gummow, Hayne and Callinan JJ).

68 Peter Cane, The Anatomy of Tort Law (Hart Publishing, 1997) 35. Good faith protections are therefore exceptions to 'the general rule that, if conduct is presumptively unlawful, a good motive will not exonerate the defendant': Three Rivers District Council v Governor and Company of the Bank of England [No 3] [2003] 2 AC 1, 190 (Lord Steyn), quoting W V H Rogers, Winfield and Jolowicz on Tort (Sweet $\&$ Maxwell, $15^{\text {th }}$ ed, 1998) 55.

69 See, eg, Rumble v Liverpool Plains Shire Council [2012] NSWDC 95. In that case, council officers trespassed on land in the belief that they were authorised to do so by certain orders issued under the Environmental Planning and Assessment Act 1979 (NSW): at [14]-[24] (Mahony DCJ).

70 See, eg, Little $v$ Commonwealth (1947) 75 CLR 94. In that case, police officers mistakenly detained a plaintiff in the belief that he had offended, and would again offend, against an order issued pursuant to the National Security (General) Regulations made under the National Security Act 1939 (Cth): at 96-7 (Dixon J). See also Hermann v Seneschal (1862) 13 CB (NS) 392; 143 ER 156; Selmes v Judge (1871) LR 6 QB 724; Webster v Lampard (1993) 177 CLR 598. 
motives so as to secure to defendants the protection intended for them in circumstances of evidential uncertainty. ${ }^{71}$ Dixon $\mathrm{J}$ came close to acknowledging this point in Little $v$ Commonwealth:

The truth is that a man acts in pursuance of a statutory provision when he is honestly engaged in a course of action that falls within the general purpose of the provision. The explanation of his failure to keep within his authority or comply with the conditions governing its exercise may lie in mistake of fact, default in care or judgment, or ignorance or mistake of law. But these are reasons which explain why he needs the protection of the provision and may at the same time justify the conclusion that he acted bona fide in the course he adopted and that it amounted to an attempt to do what is in fact within the purpose of the substantive enactment. ${ }^{72}$

By accepting that proof of an honest belief might suffice as proof of a good faith motive, the courts recognise and give effect to the strong public interest in freeing public servants and others 'from technical difficulties in conducting their defence' and 'from the heavy costs which must follow a verdict against them'. ${ }^{73}$ For the same reasons of policy, however, it seems highly unlikely that proof of an honest belief could ever defeat liability if it were proved that the defendant was, nevertheless, motivated to act other than in good faith. ${ }^{74}$ Thus, in Newell $v$ Starkie, Lord Finlay held that a protection ostensibly afforded to police officers by section 1 of the Public Authorities Protection Act 1893 (UK) c 61

necessarily will not apply if it is established that the defendant had abused his position for the purpose of acting maliciously; in that case he has not been acting within the terms of the statutory or other legal authority; he has not been bona fide endeavouring to carry it out. In such a state of facts he has abused his position for the purpose of doing a wrong, and the protection of this Act, of course, never could apply to such a case. ${ }^{75}$

Whatever the nature of the relationship between motives and beliefs, ${ }^{76}$ however, it is uncontroversial to state that motives and beliefs are both

71 It has been suggested, analogously, that the second limb of the tort of misfeasance in public office (knowledge and conscious indifference) might operate as a proxy for the first limb (targeted malice): see, eg, Three Rivers District Council v Governor and Company of the Bank of England [No 3] [2003] 2 AC 1, 235 (Lord Millett); John Murphy, 'Misfeasance in a Public Office: A Tort Law Misfit?' (2012) 32 Oxford Journal of Legal Studies 51, 52 n 2; Mark Aronson, 'Misfeasance in Public Office: A Very Peculiar Tort' (2011) 35 Melbourne University Law Review 1, 22.

72 (1947) 75 CLR 94, 112.

73 Thomas v Stephenson (1853) 2 El \& Bl 108, 116; 118 ER 709, 712-13 (Lord Campbell CJ).

74 This is presumably true of any defence that turns on a defendant's 'reasons' for acting, whether classified as a justification, excuse or otherwise. For example, according to John Gardner:

to be justified a verdict must not only be rationally reachable; it must also have been rationally reached. It is not enough that the reasons advanced in support of it did indeed support it if it was not arrived at for (one or more of) those reasons. An analogy: If I am under lethal attack, it is justifiable for me to kill my lethal attacker. But what if I kill her not because she is attacking me (I have no idea that she is), but rather because, say, I don't like her politics? Then the justifiable killing is unjustified ...

John Gardner, 'Tort Law and Its Theory' in John Tasioulas (ed), The Cambridge Companion to the Philosophy of Law (Cambridge University Press, 2017) (forthcoming).

75 (1919) 83 JP 113, 117.

76 A competing view is that motive and belief are alternative forms of good faith - the former is a qualifier of 'ends' and the latter is a qualifier of 'means', or 'action'. On this view, both forms of good faith may be exculpatory in their own right. One difficulty with this view, however, is that even if a person's actions 
subjective mind states (why a defendant acted, ${ }^{77}$ or what a defendant actually believed ${ }^{78}$ ). Of course, the only evidence of these subjective mind states is their objective manifestations, and proof that a defendant's motives or beliefs were reasonable might suffice as evidence of good faith. However, it is not necessary for a defendant to prove that his or her motives or beliefs were objectively reasonable. ${ }^{79}$ In Hermann $v$ Seneschal, ${ }^{80}$ for example, the defendant (a shopkeeper) mistakenly accused the plaintiff of attempting to purchase goods with a counterfeit coin and procured his arrest and detention by a police officer. At trial for an action in assault and false imprisonment the jury found that the defendant had acted in good faith in pursuance of a power of citizen's arrest conferred by statute, but that he had no reasonable grounds for believing that the plaintiff was guilty of counterfeiting. ${ }^{81}$ On appeal to the Court of Common Pleas, Erle CJ held that the

governing question for the jury was, whether the defendant really believed that the facts existed which would bring the case within the statute ... and [that he] honestly intended to put the law into force ... Whether the defendant had reasonable ground for that belief was ... a question subordinate to the governing question ... ${ }^{82}$

In summary, good faith in its core sense describes one or more of a defendant's motives for engaging in conduct, or the beliefs that guide those motives, and, to the extent that this generalisation holds true, good faith denotes a subjective state of mind.

\section{B Objective Good Faith}

Notwithstanding the conclusions reached in the preceding paragraphs, a small number of cases exist in which good faith may have been defined in purely objective terms. ${ }^{83}$ In Siano $v$ Helvering ('Siano'), Clark J observed that 'good faith' is

capable of and [has] received at least two divergent meanings. What one might call the broad or subjective view defines [good faith] as describing an actual state of mind irrespective of its producing causes ... On the other hand, many courts have construed [good faith] narrowly and objectively and have introduced criteria [such as a] ... 'want of that caution and diligence which an honest man of ordinary

are premised on a good faith belief, this belief is unlikely to defeat liability if that person's motive for acting is bad. See Gardner, 'Tort Law and its Theory', above $\mathrm{n} 74$.

77 Cane, The Anatomy of Tort Law, above n 68, 35.

78 Cane, Responsibility in Law and Morality, above n 41, 105: '[K]nowledge and belief are cognitive states about the world'.

79 Trobridge v Hardy (1955) 94 CLR 147, 157 (Fullagar J), approved in Webster v Lampard (1993) 177 CLR 598, 607-8 (Mason CJ, Deane and Dawson JJ). See also Read v Coker (1853) 13 CB 850, 861 (Jervis CJ), 863 (Maule J); 138 ER 1437, 1442 (Jervis CJ), 1442 (Maule J).

$80 \quad$ (1862) 13 CB (NS) 392; 143 ER 156.

81 Hermann $v$ Seneschal (1862) 13 CB (NS) 392, 402; 143 ER 156, 160 (Erle CJ).

82 Ibid 402-3; 160.

83 See also Hughes $v$ Buckland (1846) 15 M \& W 346, 355; 153 ER 883, 887 (Rolfe B). 
prudence is accustomed to exercise' ... [or] 'honesty of intention, and freedom from knowledge of circumstances which ought to put the holder upon inquiry'. ${ }^{84}$

Likewise, in Mid Density Developments Pty Ltd $v$ Rockdale Municipal Council ('Mid Density'), the Full Court of the Federal Court of Australia recognised that "in a particular statutory context, a criterion of "good faith" may go beyond personal honesty and the absence of malice, and may require some other quality of the state of mind or knowledge of the relevant actor'. ${ }^{85} \mathrm{Mid}$ Density concerned the application of section 582A of the Local Government Act 1919 (NSW), which (among other things) shielded local councils from liability in respect of advice furnished in good faith, or for things done or omitted to be done in good faith, in relation to 'flood liable land'. On the facts, the Council failed to consider two flood studies prior to issuing the appellant with planning certificates, as a result of which the plaintiff's development of the land became unprofitable. The Federal Court rejected the Council's argument that it had acted in good faith:

A council is reasonably to be expected to respond to an application for information of a character of the obvious significance of that sought here by recourse to its records. If the council represents that it has done so ('The above information has been taken from the Council's Records ...') then it still may have been acting in 'good faith' if a real attempt has been made, even though an error was made in the inspection or the results of the inspection were inaccurately represented in the certificate which is issued ... The statutory concept of 'good faith' with which the legislation in this case is concerned calls for more than honest ineptitude. There must be a real attempt by the authority to answer the request for information at least by recourse to the materials available to the authority. In this case there was a failure to meet that standard. ${ }^{86}$

It is not hard to appreciate why courts have, on occasion, construed good faith in a manner that avoids the need to rely on subjective criteria such as malice or honesty. As Clarke J put it in Siano:

this tendency to whittle down the popular-sense meaning of [good faith] undoubtedly arises from difficulties of proof. To indicate what a state of mind should be is one thing. That depends on extrinsic factors. To show what it actually is, is quite another. ${ }^{87}$

It might be argued, of course, that good faith can never truly denote an objective standard of conduct or belief, and that cases such as Siano and Mid Density merely stand for the proposition that a defendant may be required (as opposed to permitted) to prove that he or she was motivated to act in good faith by providing evidence of 'compliance with objective standards such as advertence to the purpose to which the power or function was exercised'. ${ }^{88}$

8413 F Supp 776, 780 (D NJ, 1936), quoting Pringle v Phillips, 5 Sandf 157, 165 (Duer J) (NY Superior Ct); Cochran v Fox Chase Bank, 58 A 117, 118 (Dean J) (Pa, 1904); Pinkerton Bros Co v Bromley, 77 NW 307, 308 (Mich, 1898).

85 (1993) 44 FCR 290, 299 (Gummow, Hill and Drummond JJ).

86 (1993) 44 FCR 290, 299-300 (Gummow, Hill and Drummond JJ).

8713 F Supp 776, 780 (D NJ, 1936). In Harlow v Fitzgerald, 457 US 800, 816-17 (Powell J) (1982), the Supreme Court of the United States offered similar reasons for abandoning good faith entirely as an element of qualified immunity.

88 Attrill v Richmond River Shire Council (1995) 38 NSWLR 545, 555 (Kirby P), referring to an argument presented by the appellants. 
However appealing this argument might be, it seems at odds with the conclusions reached in these cases. In Mid Density, for example, the standard identified (a 'real attempt') was not expressed as a proxy for good faith in the absence of any evidence as to the defendant's true motives or beliefs; rather, this standard was said to reflect directly the 'concept of "good faith" with which the legislation' was concerned. The salient question, then, is whether the criterion 'a real attempt' denotes an objective or a subjective standard, or perhaps a combination of both. ${ }^{89}$

No clear answer to this question emerges from Mid Density itself, and conflicting views are expressed in subsequent cases. In Barrett v South Australia, Bollen J concluded that a 'real attempt' would be precluded by proof of gross negligence (an ostensibly objective standard). ${ }^{90}$ However, in South Australia $v$ Clark, Perry J rejected this construction on the basis that gross negligence

will normally connote a breach of an objective standard, but there might, nonetheless, be a subjectively genuine attempt to discharge the duty. For example, an inexperienced junior officer of [a] bank may be asked to carry out a particular function which is clearly beyond him or her. It might be possible to say that he or she was guilty of gross negligence if that fell to be judged by an objective standard. Nonetheless, that person may have made a genuine attempt to discharge his or her duty, and for that reason may not properly be said to have failed to act in good faith. ${ }^{91}$

Even if it is accepted that good faith might denote a purely objective standard, however, it seems likely that this objective standard would ordinarily impose upon defendants a less exacting standard than objective reasonableness (or an absence of negligence) ${ }^{92}$ This is because, if good faith were to be construed in terms synonymous with reasonableness, it would be rendered redundant, contrary to the ordinary presumption that no 'clause, sentence, or word shall prove superfluous, void, or insignificant, if by any other construction they may all be made useful and pertinent'.$^{93}$ If it were truly the legislature's intention to condition a defence upon proof that the defendant acted reasonably then it would say so in unambiguous language; it would not muddy the waters by alluding to this requirement in the opaque language of good faith. Thus, in Mid Density, the Full Federal Court recognised that a person might act in good faith by making a

89 The view might be taken that 'good faith' involves both subjective and objective elements. Thus, for example, proof of good faith might require both that $\mathrm{D}$ genuinely believed a certain state of affairs to be true (subjective), and that $\mathrm{D}$ reached that belief by making appropriate enquiries (objective). As this view does not appear to have been taken by the courts, it is pursued no further here. However, support for this view may be found in Gardner's conclusion that, in the criminal law, justifications and excuses both involve some 'combination of subjective (explanatory) and objective (guiding) rationality': Gardner, Offences and Defences, above n 38, 109. The same may be true of all reason-based defences in tort law, although it is debatable whether tort law admits of excuses (on which more in Parts V and VI of this article).

90 (1994) 63 SASR 208, 209.

91 (1996) 66 SASR 199, 234.

92 It seems self-evident that good faith could never denote a more exacting standard than reasonableness.

$93 R v$ Berchet (1690) 1 Show KB 106, 108; 89 ER 480, 481 (Sir Bartholomew Shower) (in argument), quoted in Commonwealth v Baume (1905) 2 CLR 405, 414 (Griffith CJ), quoted in Project Blue Sky v Australian Broadcasting Authority (1998) 194 CLR 355, 382 [71] (McHugh, Gummow, Kirby and Hayne JJ). Of course, this presumption is merely a guide to statutory construction, which may be displaced by other considerations. 
real attempt to answer an enquiry put to them despite the fact that he or she does not act reasonably, such as by negligently analysing the results of that enquiry. A number of good faith protections also require a defendant to prove that he or she acted without negligence and in good faith. ${ }^{94}$ Clearly, in such instances, good faith and reasonableness cannot be synonymous.

\section{Good Faith, Rational Thought and Responsibility}

Insofar as good faith denotes a subjective mind state, a further question is whether that state of mind must be rational. The answer to this question may be important because rational thought is closely associated with theories of responsibility, ${ }^{95}$ and, if the concept of good faith is broad enough to encompass the mental states of persons who lack basic responsibility for their actions, this might bear upon the proper classification of good faith defences. Precisely why this is so will become apparent in the following Part. At this stage, however and on the assumption that a person is said to possess basic responsibility if he or she has the "capacity to be guided by reasons' ${ }^{96}$ - it suffices to make two brief observations in this regard.

First, a clear distinction exists between possessing the capacity to be guided by reason on the one hand, and actually being guided by reason on the other. A person might lack the capacity to be guided by reason through force of circumstance or disposition; ${ }^{97}$ however, a person who has the capacity to be guided by reason might nevertheless hold beliefs, or be motivated by reasons, that are not rational. To plead that one acted in good faith is not to plead that one lacked responsibility for one's actions. On the contrary, the courts presuppose that a person who claims to have acted in good faith $i s$ responsible for his or her actions, albeit that he or she may have held beliefs or been motivated to act for reasons that are not rational.

Secondly, even though a defendant who is deemed responsible for his or her actions might hold beliefs, or be motivated by reasons, that are not rational, it may be difficult to prove that a motive or belief that is not rational is genuinely held. As Williams J put it, '[i]t would be wild work if a party might give himself protection by merely saying that he believed himself acting in pursuance of a statute'. ${ }^{98}$ A person's mental state cannot be observed, it can only be inferred ex post facto from circumstantial evidence and 'that person's account of their frame of mind at the relevant time'. ${ }^{99}$ It is possible that a person might be able to adduce evidence of having acted consistently with irrational beliefs on prior occasions,

94 See, eg, Penalties and Sentences Act 1992 (Qld) s 63; Body Corporate and Community Management Act 1997 (Qld) s 101A; Adoption Act 2009 (Qld) s 321; Mental Health Act 2000 (Qld) s 536; Police Powers and Responsibilities Act 2000 (Qld) ss 38, 122, 787; Mental Health Act 2013 (Tas) s 218(3).

95 See, eg, H L A Hart, Punishment and Responsibility: Essays in the Philosophy of Law (Oxford University Press, 1968) 211-30. For Hart, 'capacity responsibility' denotes the minimum mental and physical capacities that a person must possess to be liable for wrongdoing: at 227-30.

96 Goudkamp, above n 3, 84.

97 Cane, Responsibility in Law and Morality, above n 41, 66-8.

98 Cann v Clipperton (1839) 10 Ad \& El 582, 589; 113 ER 221, 224.

99 Cane, Responsibility in Law and Morality, above n 41, 47. 
such as, for example, a belief in the supernatural. In most cases, however, circumstantial evidence is unlikely to support the conclusion that an irrational belief was honestly held precisely because it is irreconcilable with observable facts. Moreover, in the absence of any logical, let alone reasonable, grounds for holding a particular belief, it is unlikely that a person's own testimony will be probative.

In summary, good faith defences assume that the persons to whom their protection extends have the capacity for rational thought, but they do not require, subject to difficulties of proof, that those persons' beliefs or reasons for acting must be rational.

\section{DO EXISTING TAXONOMIES ACCOUNT FOR GOOD FAITH DEFENCES?}

The preceding analysis may be reduced to four critical propositions:

1. good faith protections are ubiquitous in regulatory statutes throughout the common law world and, to the extent that they are properly classified as defences, ought therefore to be included in any comprehensive taxonomy of tort law defences;

2. good faith protections may be defined as defences, even if they do not preclude injunctive relief, unless they are properly classified as indemnities or liability-shifting protections;

3 . in its core sense, good faith denotes a subjective mind state that describes one or more of a defendant's reasons or motives for engaging in impugned conduct, and in all instances good faith imposes a standard that is less exacting than objective reasonableness; and

4. all good faith defences assume that the persons to whom their protection extends possess the capacity for rational thought, but they do not require, difficulties of proof notwithstanding, that those persons' reasons for acting are necessarily rational.

If these propositions are accepted, how then - if at all - might prevailing taxonomies of tort law defences classify good faith defences? In the interests of brevity, analysis is confined here to three competing taxonomies - including Goudkamp's - which adopt similar terminologies and organising categories.

\section{A Cane's Agent-Relative Answers}

In Cane's view, most answers to liability (in tort law as in other legal areas) can be classified within one of two broad categories: those that are 'victim-relative', in that that they turn on considerations personal to the plaintiff, such as contributory negligence, illegality, consent, and assumption of risk; and those that are 'agent-relative', in that they turn on considerations 
personal to the wrongdoer. ${ }^{100}$ Answers that fall within the latter category, he tells us, can be further divided into 'three broad categories': justifications; immunities; and excuses. ${ }^{101}$ In Cane's view, justifications 'deny wrongdoing but not responsibility' and include answers such as the pursuit of self-interest, ${ }^{102}$ lawful arrest, ${ }^{103}$ statutory authority, ${ }^{104}$ consent and self defence. ${ }^{105}$ Immunities 'deny neither wrongdoing nor responsibility' but rather insulate from liability a particular group of defendants on the basis of their status, position or relationship with others, such as judges or witnesses. ${ }^{106}$ In contrast, excuses 'deny responsibility but not wrongdoing' on the basis that the defendant lacked full control:

either over their mind (as in the case of insanity or diminished responsibility) or over both body and mind (as in the case of automatism, somnambulism or hypnotism) or over external circumstances (as in the case of frustration, necessity, provocation or duress). ${ }^{107}$

Cane does not claim that these categories are exclusive to tort law, or that all of the answers that they comprise apply to tort law. Nor does he claim that all answers (in tort law or otherwise) can be classified within these categories. ${ }^{108}$ Thus, doctrines such as res judicata, ${ }^{109}$ which are neither victim-relative nor agent-relative, fall outside his system of classification. ${ }^{110}$ Since good faith defences are clearly agent-relative, this observation matters little in the current context. Nor can good faith defences be classified as excuses according to Cane's definition, as they do not deny responsibility on the basis that the defendant lacked control over his or her body, mind, or external circumstances. ${ }^{111}$

It remains to be determined, therefore, whether good faith defences ought to be classified as justifications or immunities according to Cane's taxonomy, or whether they might be classified as both. In order to answer this question it is first necessary to determine what, precisely, Cane means by 'wrongdoing'. If this term merely denotes the wrong upon which prima facie liability is established (the tortious conduct), then good faith defences are neither complete justifications (as they do not deny some wrongdoing), nor complete immunities

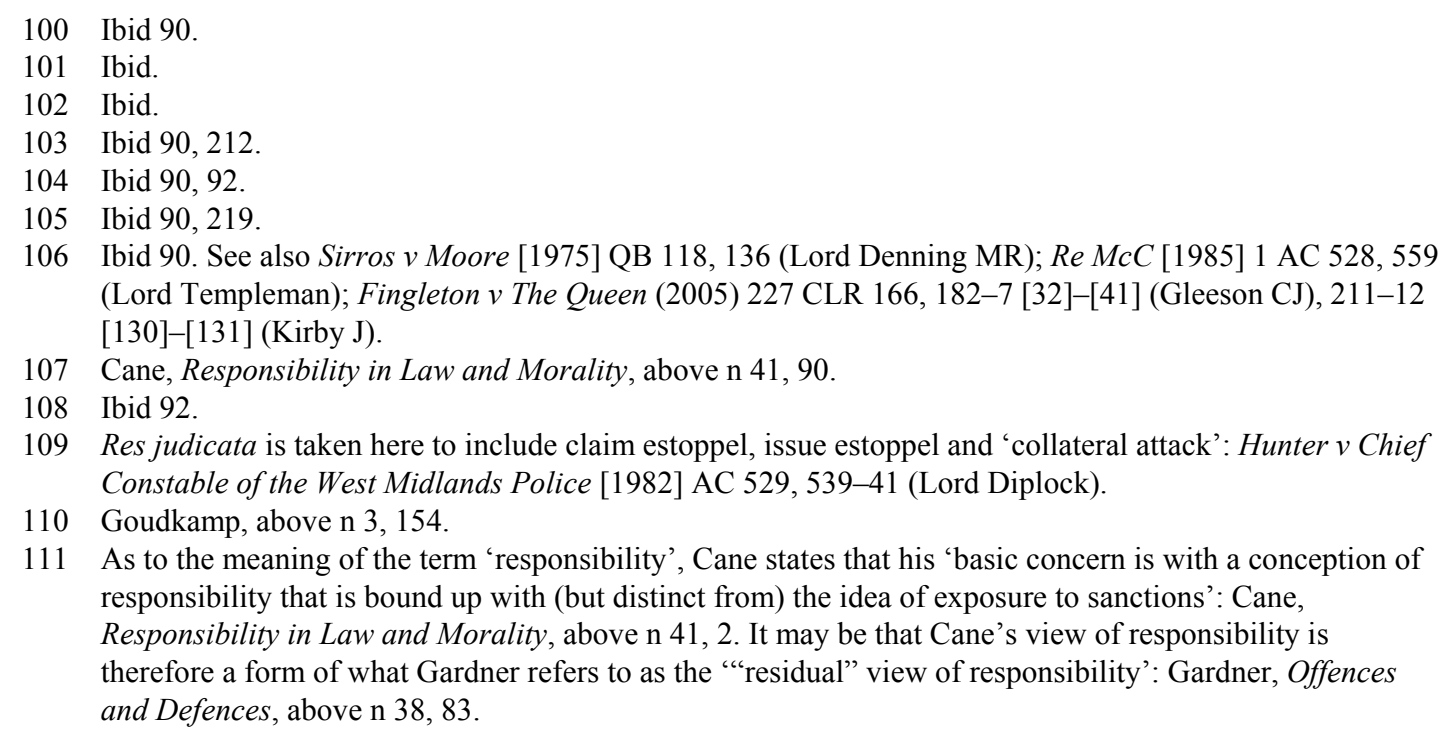


(as they are qualified by the requirement of good faith). However, it is apparent that, for Cane, wrongdoing represents the sum of the wrong upon which prima facie liability is established and the answer to that wrong. ${ }^{112}$ On this view, a good motive, such as good faith, might - 'all things considered' - justify otherwise tortious conduct. ${ }^{113}$ Thus, for example, proof of self-interest (a good motive) might justify wrongdoing for conspiring to cause economic loss by use of lawful means (an otherwise actionable wrong), notwithstanding an intention to cause economic injury. ${ }^{114}$ This conclusion accords with Cane's assertion, in an earlier article, that "good motives find their place in the concept of "justification", although not all justifications are good motives'. ${ }^{115}$ Thus, on one view at least, good faith defences ought properly to be classified as justifications according to Cane's taxonomy, since the overall effect of pleading such a defence is to accept responsibility but deny wrongdoing on the basis of a good motive. ${ }^{116}$ However, the view might also be taken that good faith defences are a form of 'qualified' immunity, on the basis that, although good faith defences are concerned with a defendant's reasons for acting, they are nevertheless strongly connected to concerns of public policy. ${ }^{117}$ It follows that Cane's system does not afford any clear answer to the question of how good faith defences ought to be classified, save that they are defendant-relative (and are not excuses). Since Cane does not claim that his categories are mutually exclusive, however, this conclusion does not necessarily reveal any error in his system of classification.

\section{B The Taxonomy Adopted by The Restatement (Second) of Torts}

A different taxonomy is suggested by the Restatement (Second) of Torts, the relevant chapters of which are entitled 'Justification and Excuse', 'Immunities' and 'Discharge'. ${ }^{118}$ The last category is not clearly defined, but it would appear to be limited to defences grounded in events that occur subsequent to tortious conduct, ${ }^{119}$ some of which might be seen as subsets of res judicata. ${ }^{120}$ Clearly,

112 Gardner describes this as the 'closure view' of wrongdoing, or 'all things considered' wrongness: Gardner, Offences and Defences, above n 38, 77, 83, 105.

113 See, to similar effect, the observation of Holmes $\mathrm{J}$ that some justifications 'may depend upon the end for which the act is done': Aikens $v$ Wisconsin 195 US 194, 204 (Wis, 1904). Cf ibid 100, for whom a justified defendant must act both reasonably and for a good ('undefeated') reason.

114 Cane, Responsibility in Law and Morality, above n 41, 90. Note, however, that proof of self-interest is probably best classified as a denial of liability (see Part III(A) of this article), since in order to establish liability the plaintiff must prove that 'the sole, the true, or the dominating, or main purpose' of the defendant's conspiracy was to cause him or her injury: McKernan v Fraser (1931) 46 CLR 343, 362 (Dixon J). This does not matter to Cane's taxonomy, however, as his concept of 'answers' appears to embrace both denials and defences: Cane, Responsibility in Law and Morality, above n 41, 89-90.

115 Peter Cane, 'Mens Rea in Tort Law' (2000) 20 Oxford Journal of Legal Studies 533, 541. Cane cites Brimelow v Casson [1924] 1 Ch 302 as an example: at 541 n 32.

116 This classification of good faith defences might seem somewhat odd, especially when the outcome of proving good faith is to relieve the primary wrongdoer of harm but to hold that wrongdoer's employer vicariously liable. For further discussion, see Part VI.

117 Cane does not in fact identify this possible sub-category of defence, although there is no obvious reason to suppose that he rejects it.

118 American Law Institute, Restatement (Second) of Torts (1979) chs 45, 45A, 46.

119 Goudkamp, above n 3, 158.

120 Such as bar by judgment, merger in judgment or statutes of limitations. 
good faith defences do not fall within this category. The Reporters distinguish between the former two categories as follows:

A justification or excuse avoids liability for tortious conduct only under particular circumstances and because those circumstances make it just and reasonable that the liability not be imposed. An immunity, on the other hand, avoids liability in tort under all circumstances, but because of the status or position of the favored defendant or his relationship with others ... Historically, all immunities were once broad in scope and quite complete within that scope. With the passage of time and the development of numerous limitations and exceptions, they have come more closely to resemble privileges and other defenses. ${ }^{121}$

The Reporters classify privileges as a species of justification. ${ }^{122}$ However, they also observe that the distinction between privileges and immunities (which are not a species of justification) is one of degree - the former being subject to a greater number of 'limitations and exceptions' than the latter. ${ }^{123}$ The limitations and exceptions to which the Reporters refer include minimum standards of conduct that must be satisfied in order to enliven the protection in question. In the context of public officials, for example, the Reporters outline four situations in which the minimum standard of conduct required - and thus the label attached to the protection afforded - differs between jurisdictions:

[In the first situation], the existence of an 'immunity' may mean that, so long as an officer acts within the general scope of his authority ... he is not liable, regardless of his motives and whether he tried to exercise his judgment in good faith or not. ... This is a full immunity - a true immunity - though it is sometimes called an absolute privilege. ...

In a second situation, the existence of the 'immunity' may be treated as meaning that the officer is not liable if he made his determination and took the action that harmed the other party in good faith, in an honest effort to do what he thought the exigencies before him required. ... It may be questioned whether this is more properly called an immunity or a privilege. ...

In a third situation, the existence of the 'immunity' may mean that the officer is not liable if his determination to take or not to take the action was reasonable. ... In an action for an intentional tort, this is accurately described as a privilege. ...

The final situation is one in which the officer is liable unless he was correct in his determination. In this case, if he was acting on the basis of a privilege, it is a privilege that must be strictly complied with to be applicable and does not apply on the basis of what he reasonably believes. ${ }^{124}$

As this extract reveals, and has already been explained, good faith defences in the US (statutory or common law) are described either as qualified immunities or privileges (ergo, justifications). Unfortunately, as the Reporters acknowledge, their exposition of the law does not reveal where immunities end and privileges, or other justifications, begin. While this might be an accurate account of the various approaches adopted in the US, it is clearly inadequate as a taxonomical tool. Nor is there any obvious reason other than convention why good faith defences in the US should not also be described as excuses, insofar as good faith

121 American Law Institute, above n 118, ch 45A (Introductory Note).

122 Ibid $\S 890$.

123 Clearly, then, the Reporters do not attempt to construct rigid boundaries between these categories: Goudkamp, above n 3, 158.

124 American Law Institute, above n 118, § 895D. 
might be seen as a circumstance that makes 'it just and reasonable that the liability not be imposed'. ${ }^{25}$

\section{Goudkamp's Bipartite Classification}

Goudkamp rejects the taxonomies adopted by Cane, the Restatement (Second) of Torts and others on the basis, inter alia, that they suffer from imprecise, overlapping or non-exhaustive boundaries. ${ }^{126} \mathrm{He}$ refutes entirely the existence of excuses in tort law, ${ }^{127}$ and argues that all tort law defences may be classified within two broad categories: (1) justification defences; and (2) public policy defences. This bipartite classification, Goudkamp contends, provides an exhaustive account of tort law defences, including, it would appear, statutory defences. Goudkamp's reasons for rejecting excuses are considered shortly. Before doing so, however, it is necessary to examine in more detail what he means by 'justification defences' and 'public policy defences', and to identify the critical distinction that he draws between these two categories.

Goudkamp defines public policy defences as 'defences that are insensitive to the rational defensibility of the defendant's conduct'. ${ }^{128}$ Thus, section 329 of the Criminal Justice Act 2003 (UK) c 44 creates a public policy defence, 'since it may apply even if the defendant acted unreasonably, such as by using disproportionate force against the claimant, or by proceeding on the basis of an incorrect and unreasonable belief that it was necessary to use force'. ${ }^{129}$ It follows that immunities are public policy defences, in Goudkamp's view, as 'their application is not dependent on the reasonableness of the defendant's impugned behaviour'. ${ }^{130}$ Since a defendant who advances a public policy defence 'does not attempt to explain why he committed a tort', Goudkamp explains, ${ }^{131}$

[t] he defendant's motive is obviously irrelevant to public policy defences ... The defendant's conduct need not be supported by an undefeated reason or, indeed, any reason. Naturally, therefore, public policy defences are not in the slightest bit interested in the defendant's reasons for acting. ${ }^{132}$

In contrast, Goudkamp defines justifications as defences that 'relieve the defendant of liability on the ground that he [or she] acted reasonably in committing a tort', ${ }^{133}$ such as self-defence, defence of one's property or qualified privilege. ${ }^{134}$ In making this claim, Goudkamp endorses the 'reasons' theory of justification, as opposed to the 'conduct' or 'deeds' theory. ${ }^{135}$ Thus, a defendant

125 Ibid ch 45A (Introductory Note).

126 Goudkamp, above n 3, ch 7.

127 Ibid 82-101.

128 Ibid 76.

129 Ibid 127 (citations omitted).

130 Ibid 123. Goudkamp does not distinguish between immunities and other public policy defences, such as privileges, with the exception of qualified privilege, which he classifies as a justification: at 110-11.

131 Ibid 76.

132 Ibid 142. The term 'undefeated reason' appears here to be used in the sense defined in Gardner, Offences and Defences, above $\mathrm{n} 38,100$; that is to say, 'that at least one of the (guiding) reasons in favour of doing as one did should have been one's (explanatory) reason for doing it'.

133 Goudkamp, above n 3, 105. See also Goldberg, 'Tort Law's Missing Excuses', above n 17, 53-4.

134 Goudkamp, above n 3, 105-22.

135 Ibid 90-7. 
who acts 'on the basis of a reasonable mistake about the existence of justifying facts' is also properly said to be justified. ${ }^{136}$ It is apparent that Goudkamp intends the term 'reasonable' to be read in its orthodox legal sense - as an objective standard measured against the reasonable person - as opposed to some broader concept that might, in certain instances, encompass other reasons for acting, such as a good motive or an unreasonable yet honest mistaken belief. ${ }^{137}$ On this basis, Goudkamp states that there 'is no logical space for any justificatory defences to negligence because negligence can be committed only if one acted unreasonably, which is simply another way of saying that one acted without justification'. ${ }^{138}$ Certainly, all but one of the justification defences that Goudkamp identifies - the defence of consent ${ }^{139}$ - require defendants to have acted in a manner, or on the basis of a belief, that was objectively reasonable. ${ }^{140}$

If the preceding interpretations are correct, then the upshot of Goudkamp's taxonomy is to divide tort law defences into those defences that operate only when a person's conduct or mistaken belief is reasonable in the circumstances (in which case a defendant is said to be justified), and those defences that do not, by definition, require a defendant to have acted for any particular reason at all (in which case the defence must be one of public policy). So interpreted, neither category is 'sensitive' to a good faith motive or an unreasonable yet honest mistaken belief. This is not to say, however, that Goudkamp offers no insight at all into to how good faith defences might be classified. In fact, good faith defences fit neatly within his definition of 'excuses'. In order to explain why this so, it is necessary to explore in some detail what Goudkamp means by the term excuses, and to determine why he refutes the existence of such defences in tort law.

Goudkamp's argument that tort law does not recognise excuses unfolds in three stages. First, he argues that many supposed excuses in tort law such as insanity and incapacity are in fact denials of 'basic responsibility' - that is, the 'capacity to be guided by reasons' - and ought therefore 'to be ignored in considering whether tort law admits of excuses'. ${ }^{141}$ Good faith defences do not deny basic responsibility, hence they do not pose a challenge to this conclusion. Secondly, Goudkamp argues that several other "pleas that are widely accepted as excuses do not deny the defendant's responsibility in the basic sense'. ${ }^{142} \mathrm{He}$ offers provocation as an example of such a plea:

\footnotetext{
136 Ibid 96-7.

137 Ibid 86.

138 Ibid 9.

139 Consent may be a defence, Goudkamp argues, if it is pleaded as an answer to torts that 'do not treat the lack of consent as a definitional matter. These torts include defamation, private nuisance and the action in Rylands v Fletcher': ibid 113. Consent is a justification in this context, in Goudkamp's view, because 'D must act in reliance on the fact that $\mathrm{C}$ consented': at 114 .

140 For example, Goudkamp classifies statutory authority as a justification on the basis that it is subject to the "qualification, or condition, that the statutory powers are exercised without "negligence": Goudkamp, above n 3, 122, quoting Allen v Gulf Oil Refining Ltd [1981] AC 1001, 1011 (Lord Wilberforce).

141 Goudkamp, above n 3, 84-5.

142 Ibid.
} 
A defendant who kills in response to provocation may have suffered a loss of selfcontrol, but this does not mean that such a defendant will be unable to explain himself rationally. ... [Thus,] the better view is that a defendant who claims an excuse actually endeavours to demonstrate that he was operating within the realm of reason. ${ }^{143}$

On this view, the distinction between an excuse and a public policy defence is that excuses are sensitive to certain reasons, whereas public policy defences are not, and the distinction between an excuse and a justification is that

an excused defendant, while still offering a rational explanation for his conduct, does not assert that his conduct was reasonable. Although there were one or more reasons for an excused defendant to do that which he did, those reasons were insufficiently strong to result in the defendant being justified in his acts. ${ }^{144}$

If tort law were to recognise defences that satisfy this narrow definition then - according to Goudkamp - it would be necessary to reserve a separate category for excuses. ${ }^{145}$ However, in the third stage of his argument, Goudkamp asserts that the pleas ordinarily regarded as excuses in this narrow sense - provocation, duress, and 'excessive self-defence' - either fail to satisfy his definition of defences or ought to be classified as justifications. Provocation is not a defence, he concludes, because the effect of successfully invoking this plea is merely to diminish damages, ${ }^{146}$ and duress is unlikely to be a defence given the 'scarcity of relevant authority' to this effect. ${ }^{147}$ Excessive self-defence may be a defence but not an excuse, Goudkamp argues, as a person who mistakenly but reasonably believes that he or she is acting in self-defence is properly said to be justified, ${ }^{148}$ whereas a person who performs a justified act for a bad reason ordinarily has no defence at all. ${ }^{149}$ Since he can find no evidence of excuses in the sense that he defines them, Goudkamp concludes that there is no need to reserve a separate category for excuses. ${ }^{150}$

However, Goudkamp does not address the possibility that a defence might defeat liability if a person's mistaken belief is unreasonable yet honest, or if a person's conduct is unreasonable but his or her motives are good. Since good

143 Ibid 85.

144 Ibid 86. See also Goldberg, 'Inexcusable Wrongs', above n 17, 472-4 (citations omitted) (emphasis in original):

Unlike a justification, an excuse not only concedes that the actor's conduct meets the definition of the alleged wrong, but also that the conduct was wrongful when all things are considered. ... An effort at an excuse will be credible only if it offers an explanation of a wrong that renders it understandable in light of norms as to how persons are supposed to handle situations in which it is more difficult than usual to do

145 Ibid 83. the right thing.

146 Ibid 88.

147 Ibid 89. Cf James Edelman and Esther Dyer, 'A Defence of Duress in the Law of Torts?' in Andrew Dyson, James Goudkamp and Frederick Wilmot-Smith (eds), Defences in Tort (Hart Publishing, 2015) 159 , who challenge the conventional view that duress is not a defence in tort law.

148 Goudkamp, above n 3, 90-7. According to John Gardner, the criminal law would treat a defendant who mistakenly but reasonably believes that he or she is acting in self-defence as being excused: Gardner, Offences and Defences, above n 38, 113. See also Cane, Responsibility in Law and Morality, above n 41, 90.

149 Goudkamp, above n 3, 97-100. See also Gardner, Offences and Defences, above n 38, 100.

150 Goudkamp, above n 3, 101. Curiously, however, Goudkamp classifies honest comment as a public policy defence, despite the fact that this defence turns on proof of an honestly held opinion (an excuse): at 126. 
faith defences defeat liability in both of these scenarios, and assuming they are not classified as denials, it follows that they are excuses according to Goudkamp's definition.

In summary, it would appear that Goudkamp's taxonomy reserves no place for defences, as opposed to denials, which turn upon exculpatory reasons that are insufficient to render the defendant's conduct or mistaken beliefs objectively reasonable, such as a good motive or an honest but unreasonable mistake. In order to account for good faith defences - or any other defence that is sensitive to such reasons ${ }^{151}$ - Goudkamp's taxonomy must be modified in one of three ways:

1. public policy defences must be reclassified as being sensitive to certain reasons, such as good faith, that are insufficiently strong to render the defendant's conduct objectively reasonable;

2. the term 'reasonable' (the unifying feature of justifications) must be interpreted as including reasons, such as good faith, which are insufficiently strong to render the defendant's conduct objectively reasonable; or

3. a separate category must be reserved for excuses (in the sense defined by Goudkamp).

The first option is consistent with Goudkamp's subsequent classification of the good faith protections conferred on 'good samaritans' and volunteers by certain Australian 'civil liability acts' ${ }^{152}$ as immunities, ${ }^{153}$ and therefore public policy defences. ${ }^{154}$ It is doubtful, however, whether this option provides much of a solution to Goudkamp's definitional shortfall. If the boundaries of public policy defences were redrawn so as to encapsulate defences sensitive to reasons such as good faith, the result would be to create little more than a residual category, the scope of which is so broad and the content of which is so divergent as to belie any meaningful taxonomical purpose. ${ }^{155}$ In the absence of some unifying feature, other than the fact that they exclude justifications, it is difficult to see how it might be useful to label such a broad range of protections as 'public policy defences'. In this regard, the reader might recall Catala and Weir's observation

151 Such as, for example, the defence of fair comment.

That is to say, the various statutes implemented by the Australian states and territories in response to the 'Ipp Report': David Andrew Ipp et al, 'Review of the Law of Negligence' (Final Report, September 2002); Commonwealth Volunteers Protection Act 2003 (Cth) ss 6-7; Civil Law (Wrongs) Act 2002 (ACT) ss 8-9; Civil Liability Act 2002 (NSW) s 61; Personal Injuries (Liability and Damages) Act 2003 (NT) s 7; Civil Liability Act 2003 (Qld) s 39; Volunteers Protection Act 2001 (SA) s 4; Civil Liability Act 2002 (Tas) s 47; Wrongs Act 1958 (Vic) s 37; Volunteers and Food and Other Donors (Protection from Liability) Act 2002 (WA) ss 6-7.

153 James Goudkamp, 'Statutes and Tort Defences' in T T Arvind and Jenny Steel (eds), Tort Law and the Legislature: Common Law, Statute and the Dynamics of Legal Change (Hart Publishing, 2013) 31, 45-6. This conclusion is also consistent with the treatment afforded by the Restatement (Second) of Torts to the defences available to public officials: see text accompanying above n 124 .

154 See text accompanying above $\mathrm{n} 132$.

155 Even if public policy defences are confined to defences that are insensitive to reasons, Goudkamp's category of 'public policy defences' bears more than a passing resemblance to Birks' category of 'other' obligations: see, eg, Peter Birks, 'Equity in the Modern World: An Exercise in Taxonomy' (1996) 26 University of Western Australia Law Review 1, 8-11. 
that "[a]ny general principle back of all the torts we know can be no lower in abstraction than "public policy"; and it is the root of all liability, the measure of none'. ${ }^{156}$

The second option might provide a better solution. If this option is favoured, then Goudkamp's definition of justifications converges with Cane's. Putting aside the fact that Goudkamp clearly rejects this definition, it need not necessarily threaten his bipartite classification to concede that a person of sound mind who acts in good faith - or for some other reason that is insufficiently strong to render that person's conduct or belief reasonable - is justified. However, just as classifying good faith defences as public policy defences might render that category of defences overly broad and diverse, so too might classifying good faith defences as justifications render that category overly broad and diverse.

In the result, the third option might prove the least disruptive to Goudkamp's basic thesis, ${ }^{157}$ as this would merely require the population of what is an otherwise empty category. If this option were favoured, then the distinction between justifications and excuses would lie in the nature of the exculpatory reasons upon which they turn (reasonableness, good faith, honesty, and so forth), and Goudkamp's bipartite classification would be transformed into a tripartite system of defences that is 'nested' according to the nature of the exculpatory reasons, if any, upon which these defences turn. ${ }^{158}$

\section{HOW SHOULD GOOD FAITH DEFENCES BE CLASSIFIED?}

How, then, should good faith defences be classified? In the light of the preceding analysis, it seems sensible to conclude that good faith defences are best viewed either as justifications or excuses. There is no definitive reason as to why good faith defences should not be described as (qualified) immunities, as suggested by Goudkamp and various others, ${ }^{159}$ and as is the case certain American jurisdictions. However, unlike immunities, justifications (including, perhaps, certain privileges) ${ }^{160}$ and excuses are ultimately concerned with the reasons that guide and explain a person's otherwise tortious conduct. Framing good faith defences as immunities might discourage the articulation of general

156 Pierre Catala and John Anthony Weir, 'Delict and Torts: A Study in Parallel: Part I' (1963) 37 Tulane Law Review 573, 580.

157 See, eg, the definitions of excuse offered in Mitchell N Berman, 'Justification and Excuse, Law and Morality' (2003) 53 Duke Law Journal 1, 5; Graham Virgo, 'Justifying Necessity as a Defence in Tort Law' in Andrew Dyson, James Goudkamp and Frederick Wilmot-Smith (eds), Defences in Tort (Hart Publishing, 2015) 135, 140-1.

158 Ibid 88. See also Field, 'Good Faith Defences in Tort Law', above n 35, 161-6.

159 Goudkamp, 'Statutes and Tort Defences', above n 153, 45-6. See also Bankstown City Council v Alamdo Holdings Pty Ltd (2005) 223 CLR 660, 674 [47] (Gleeson CJ, Gummow, Hayne and Callinan JJ); Attrill v Richmond River Shire Council (1995) 38 NSWLR 545, 553 (Kirby P).

160 Since the preceding analysis (and the literature generally) reveals no clear definition of privileges, the possibility that good faith defences might be classified as privileges is not pursued further here: $\mathrm{cf}$ Edelman and Dyer, above n 147, 180-1. 
principles that explain the implications of this unifying feature, ${ }^{161}$ or obscure the affinity between good faith defences and other reason-based defences, ${ }^{162}$ by overstating the interpretive significance of the specific public policy objectives that individual defences seek to achieve. This is not to say, of course, that public policy should be ignored when interpreting good faith defences. Clearly, identifying why the legislature has afforded protection to a limited class of defendant, whose reasons are insufficient to render their conduct or belief reasonable, may be critical to properly interpreting the scope of the protection afforded. As noted above, however, all defences to liability, including common law defences, are ultimately grounded in considerations of public policy. ${ }^{163}$ Moreover, whereas the requirement of good faith is evident on the face of all good faith defences, the public policy considerations that led to the creation of those defences are not.

This leaves open the question of whether good faith defences should be classified as justifications, excuses or some other category of defence. The answer to this question may be of some practical importance, as it may influence the substantive interpretation afforded to a good faith defence by a court. It may also be of interest to taxonomists as it bears directly upon the (highly controversial) question of whether or not tort law recognises excuses. For the most part, those who accept that tort law recognises excuses point to rules that 'creep in at tort law's margins'. ${ }^{164}$ Such rules may be dismissed as taxonomical outliers. In contrast, good faith defences are both ubiquitous and the subject of a considerable body of case law. Thus, if good faith defences are properly defined as excuses, this cannot be ignored in a taxonomical account of tort law defences.

Of course, whether good faith defences are excuses depends entirely upon how this term is defined in the first place and where the boundary between excuses and justifications is located. Various competing definitions of the term 'excuse' emerge from the literature; however, there is no obvious or compelling reason to insist upon any particular one. This being so, scholars are likely to adopt definitions that best suit their analytical needs or theoretical biases. In some instances, for example, it might be convenient to define excuses as defences that turn on reasons for acting, which, while borne of or influencing a rational mind, are insufficiently strong to render conduct or beliefs reasonable, and to reserve the term justification for defences that are unified by the requirement that the defendant acted reasonably, as suggested by Goudkamp. Framing the relationship between excuses and justifications in this way might prove useful for various reasons, not least because the practical utility of an excuse would rest, in part, upon the range of circumstances in which it might

161 These implications are considered in Field, 'Good Faith Defences in Tort Law', above n 35, 154-5.

162 Dietrich, above n 5, 558.

163 See Catala and Weir, above n 156, 580.

164 Dyson, Goudkamp and Wilmot-Smith, 'Central Themes in the Law of Tort Defences', above n 6, 22. For example, Goldberg has conceded that a defendant who acts in self-defence on the basis of a reasonable but mistaken belief may be 'excused': Goldberg, 'Tort Law's Missing Excuses', above n 17, 55. Cf Goudkamp, above n 3, 90-7, who argues that such a defendant may be 'justified', referred to at text accompanying above nn 148-9. Virgo argues that private necessity may be an excuse in certain instances: Virgo, above n 157, 141. 
provide a defence that would not otherwise be available on the basis that the defendant was justified.

On the other hand, it might be expedient to define justifications as including all defences that are concerned with a defendant's reasons for acting, and to reserve the term excuses for denials of responsibility based on unsoundness of mind and, perhaps, external circumstances, as suggested by Cane. This definitional approach might prove especially useful when a statutory defence comprises more than one exculpatory criteria - such as, for example, a defence that requires conduct to be done in 'good faith' and 'without negligence'. ${ }^{165}$ It would be thoroughly confusing, not to mention intolerable for the doctrinal taxonomist, to classify such a defence as 'part' excuse and 'part' justification. ${ }^{166}$ Distinguishing between justifications and excuses in this way might also facilitate the analysis of defences that adopt different exculpatory reasons, such as reasonableness, good faith, honesty and so forth, without the need to maintain a conceptual distinction between reasons that amount to excuses on the one hand, and reasons that amount to justifications on the other. ${ }^{167}$

\section{CONCLUSION}

This article has demonstrated that good faith protections present a series of challenges to the taxonomy of tort law defences. It has shown that good faith (and other similar) protections might frustrate attempts to articulate a universal definition of defences because some good faith protections, while defeating the liability of one party, shift liability (and thus create liability) against another party, while other good faith protections are likely to defeat liability in damages while preserving the possibility of injunctive relief. This article has also argued that good faith defences should be classified either as justifications or excuses because good faith describes a person's reasons for acting, and classifying good faith defences as immunities or privileges might encourage the divination of specific public policy objectives at the expense of developing general principles. This would be inconsistent with the treatment historically afforded to good faith defences, and is clearly undesirable from a taxonomical perspective. These conclusions sit uneasily with certain taxonomies of tort law defences, which might now repay further consideration.

165 See examples cited at above $\mathrm{n} 94$.

166 It seems likely that Goudkamp would classify such a defence as a justification, as the defendant's impugned conduct must still be reasonable for the defence to apply, notwithstanding that good faith must also be proved: Goudkamp, above n 3, 105. Thus, it might be that for Goudkamp, whether a good faith defence is a justification or an excuse depends upon whether: (a) good faith is the sole exculpatory criterion, in which case it is an excuse; or (b) good faith forms part of a complex exculpatory criterion that also requires the defendant to have acted reasonably, in which case it is a justification.

167 See, eg, the approach adopted in Field, 'Good Faith Defences in Tort Law', above n 35, 154. 